\title{
Nejdř́v byli dinosauři a pak se narodila prababička aneb Chvála etnografie ve výzkumu dětí
}

\author{
First there were Dinosours and then our Great-grandmother \\ was Born: Honoring Ethnography in Childhood Research
}

Lucie Jarkovská

\begin{abstract}
This article focuses on the methodological dilemmas of conducting research with children and illustrates those dilemmas with examples from Czech and international studies. New approaches to childhood studies emphasize the understanding of the child as a competent, autonomous and equal partner of the researcher. Although sociologists strive to emphasize children's perspectives, sociological research, in its essence, objectifies child subjects and applies to them categories of its own paradigm. Nonetheless, in new childhood studies it is legitimate and inevitable that researchers will overcome this paternalistic approach. For this reason, researchers must conscientiously examine their own assumptions and theoretical and methodological approaches stemming from the discipline as well as the adult position. The main argument of the article suggests that in the research of children we can exercise various techniques such as questionnaires, individual and group interviews or creative techniques such as writing, drawing or drama, but without long term observations and experience in the research field the children's standpoint cannot be comprehended.
\end{abstract}

KEY WORDS childhood studies, methodology, ethnography, informed consent

Intro

A jak žil ten Kolumbus, tak to už jsi ty, mámo, byla na světě?

A ten můj panáček, ten je starý, strašně starý. Mu je... eee... jemu je... přinejmenším šestnáct!

Nejdř́v byli dinosauři, potom mamuti a pak se narodila naše prababička. ${ }^{2}$

\section{Dítě pod drobnohledem sociologického výzkumu}

Dítě a dětství se staly předmětem zájmu vědy se vznikem industrializované, urbanizované a především racionálně organizované společnosti $v$ druhé polovině devatenáctého

Sociální studia. Katedra sociologie FSS MU, 2/2012. S. 31-42. ISSN 1214-813X.

1 Tento text vznikl s podporou Grantové agentury České republiky v rámci výzkumného záměru „Vzdělávací strategie dětí migrantů a dětí z etnických menšin“ (P404/12/1487).

2 Výpovědi Helenky a Marianny, dcer blogerky, která si ř́́ká pepperann a publikuje na blogu $<$ http://coslychacudziewczynek.blox.pl $>$ 
a na začátku dvacátého století. Podle Woodheada jde zájem sociálních věd o dítě ruku $\mathrm{v}$ ruce $\mathrm{s}$ rozšîřením praktických profesí a institucí zabývajících se dětstvím, jako jsou pečovatelky o děti, školy, pediatričtí lékaři. Všechny tyto subjekty měly zájem získat vědecké poznatky o dětství, které by jim posloužily jako nástroje využitelné v jejich profesní činnosti (Woodhead 2008: 18). ${ }^{3} \mathrm{~V}$ té době byla věda budována na pozitivistických předpokladech, dětství bylo pojímáno jako biologicky daný fakt a pozornost vědy se soustředila především na aspekty vývoje dítěte $\mathrm{v}$ dospělého. Dítě bylo vnímáno jako biologicky a sociálně nezralý jedinec a hlavním cílem studií bylo přispět ke zdravému vývoji dítěte po zdravotní, psychické i sociální stránce. Tyto myšlenky jsou základem vývojových teorií, které od 19. století až do druhé poloviny století dvacátého tvořily podle Prouta a James (1997: 10-14) tzv. dominantní rámec studií dětství.

$\mathrm{V}$ druhé polovině dvacátého století dochází $\mathrm{k}$ radikální změně pojímání dětství, které je nově konceptualizováno jako historický konstrukt. Za jednoho z prvních, kdo zpochybňuje biologickou podstatu dětství a představu o „pririrozenosti“ dětství a kdo poukazuje na jeho sociální a historickou proměnlivost, je považován sociální historik Philippe Áries. Ve svém vlivném díle dokazuje, že se $\mathrm{v}$ různých historických obdobích postoje $\mathrm{k}$ dětem proměňovaly a koncept dětství je výsledkem právě určitého způsobu uvažování o dětech. Uvádí, že děti ve stř̌edověku neměly žádný zvláštní status, mezi dítětem a dospělým neexistovala žádná distinktivní hranice. Až moderní evropská společnost se začala o děti starat jako o specifickou skupinu se specifickými potřebami a zahrnula dětství zvýšeným zájmem, především právě z hlediska zdravého vývoje a prosperity (Áries 1962).

Dalším, kdo přispěl k posunu v teoriích týkajících se dětství, byl Edward Shorter (1976), který se soustředil na vývoj moderní nukleární rodiny. Čerpal především ze srovnání premoderního mateřství osmnáctého století a moderního mateřství století dvacátého. Na tomto srovnání Shorter ukazuje, že děti v premoderní době neměly v životě žen nijak zvláštní úlohu, nebyly o nic důležitější než jiné aspekty života žen. To dokládá faktem, že tehdejší ženy se dětem neobětovávaly, nevnímaly je jako středobod své existence a jejich př́istup $\mathrm{k}$ dětem by z dnešního pohledu byl vnímán jako zanedbávání či dokonce zneužívání. Shorter poukazuje na to, že konstrukce moderního konceptu západního dětství úzce souvisí s historickým vývojem konceptu matersství. ${ }^{4}$

Utilitární pozitivistický zájem o dětství přinesl dětem mnoho pozitivního - zlepšení jejich životních podmínek, zákaz dětské práce či zpochybnění (ponejprv těžkých) fyzických trestů. Na druhé straně byl později od šedesátých let dvacátého století kritizován za to, že redukuje bytosti bez volebního práva na nehotové entity, žijící jakýsi předživot a připravující se na život skutečný. Jeho kritika šla ruku v ruce s kritikou androcentrismu vědy (Millman a Kanter 1975, Harding 1986). Teorie, které věda nabízela, byly vytvořeny dospělými vědci-muži a zahrnovaly mužskou zkušenost, kterou věda považovala za normu. Při aplikaci těchto

3 Zároveň však lze říci, že zvyšující se počet profesí zaměřených na práci s dětmi byl důsledkem vědeckého poznání, které pojmenovalo dětství jako cosi specifického, co si zasluhuje speciální pozornost a péči.

4 Podobně ukazuje francouzská historička a filosofka Élisabeth Badinter, jakým způsobem je mateřství prostřednictvím pojetí dětství, dítěte a dětských potřeb využíváno k politickým zájmům (1998). 
teorií na děti či ženy se jejich zkušenost často jevila jako deviantní, ženy i děti jako neúplné, nedokonalé, selhávající, popřípadě vůbec do těchto teorií nezapadající. Dítě bylo v sociálních vědách dlouho pojímáno (stejně tak žena) jako inferiorní a nekompetentní sociální aktér (Wyness 2006: 38). Qvortrup tvrdí, že děti byly marginalizovány v sociologii, protože jsou marginalizovány i ve společnosti (Qvortrup in Corsaro 1997: 7). Na rozdíl od jiných marginalizovaných skupin však nemají své zástupce a zástupkyně mezi sociology a nestojí za nimi silné „dětské“ hnutí usilující o emancipaci tak, jak tomu bylo v př́ípadě žen.

Kritické rozpoznání paralel mezi postavením žen a dětí (popř́ípadě jiných marginalizovaných) ve společnosti $\mathrm{i}$ ve vědě vedlo $\mathrm{k}$ ustavení tzv. studií dětství (childhood studies), jejichž hlavním cílem je zahrnutí dětského hlasu do vědeckého způsobu vypovídání o světě. Nové př́stupy zdůrazňují pojetí dítěte jako kompetentního, autonomního a rovnocenného partnera ve výzkumu. Co bylo po dlouhá léta vnímáno jako dětství vlastní a přirozené, je nyní přezkoumáváno jako sociálně konstruované, a proto také vždy politické. Studia dětství se formují jako explicitně angažovaná vědní disciplína a výzkumníci a výzkumnice usilují o kritický pohled na to, jakým způsobem jsou životy dětí organizovány a regulovány, jak se proměňují v čase a v souvislosti s kategoriemi jako místo, věk, gender, etnicita či tř́́da (Alanen 2011: 147). Zmíněné ustavující myšlenky představují epistemologicky nový př́stup, který podněcuje i inovace metodologické. $V$ tomto textu se budu věnovat právě promýšlení toho, jaké implikace mají nové př́stupy při výzkumu dětí a výzkumu s dětmi pro metodologii, a zda je možné ideálům studií dětství metodologicky dostát.

\section{Jak zkoumat dětský svět?}

Jak jsem již zmínila výše, studia dětství si kladou za cíl uplatňovat ve výzkumu perspektivu dětí. Otázka číslo jedna však zní: Nakolik je to vůbec možné? Sociologický výzkum je ze své podstaty něčím, co z dítěte nutně dělá objekt a uplatňuje na něj kategorie vlastní disciplíny, jakkoli usiluje o vyzdvižení dětské perspektivy. Je to, co považujeme za vědu a vědecký způsob vypovídání o světě, kompatibilní se zájmy dětí a s jejich způsobem přemýšlení a vypovídání o světě? Mají děti zájem o to, aby jejich hlas byl ve vědě slyšet? Mají děti zájem „dělat vědu“"? Ve výzkumu dětí se obvykle toto dilema řeší snahou dětem vysvětlit, co je cílem výzkumnice/výzkumníka a jejich studie, a získáním informovaného souhlasu. Thorne např́klad uvádí, že děti v jejím výzkumu byly nadšené z toho, že věděly, že o nich vyjde kniha. Je však otázkou, jestli, pokud by dostaly možnost vybrat si, zda chtějí, aby o nich vyšla sociologická kniha, nebo o nich byl natočen muzikál, by nedaly přednost muzikálu. Ačkoli bych sázela na druhou možnost, nedomnívám se, že by to mělo znamenat, že se máme cíle zahrnout do výzkumu dětský hlas vzdát. Na druhé straně bychom se jako výzkumnice a výzkumníci měli zamyslet nad tím, zda klasický odborný text je tím jediným možným výstupem $\mathrm{z}$ našeho projektu. Při jedné ze svých cest do Polska jsem narazila na velmi zajímavou publikaci, která se jmenuje Chudoba. Učebnice pro děti (Bieda. Przewodnik dla dzieci), autorkami jsou Hanna Gill-Piątek a Henrika Krzywonos, ilustrátorkou Anna Pluta (2010). Tato knížka se pokouší odpovědět dětem na otázku výsostně sociologické povahy - odkud se bere bída? Způsob, jakým text kombinuje konkrétní príběhy ilustrující kořeny chudoby i její důsledky pro dětský život s obecnými statistickými údaji o chudobě v Polsku i ve světě, je nádhernou 
ukázkou toho, že dětem lze komunikovat sociologické poznatky formou, která je pro ně srozumitelná, a přitom není schematizující, hrubě zjednodušující ani zavádějící. Př́iběhy dětí, které se v knížce objevují ve vyprávění malé Anky, vycházejí z konkrétních zkušeností dětí potýkajících se s chudobou a navštěvujících volnočasová centra, tzv. świetlice. Knížka je tedy založena na kvalitativním výzkumu realizovaném s dětmi, a zároveň jeho výsledky prezentuje způsobem, ze kterého mohou děti přímo profitovat.

Je pravda, že ne každý sociolog či socioložka mají nadání vytvářet knihy pro děti, nebo by třeba dokázali vytvořit krátký film, vzdělávací pořad, workshop či jiný produkt pro děti zajímavější než je odborná publikace. Domnívám se ale, že by badatelky a badatelé z oblasti studií dětství měli být kreativní a měli vytvářet pracovní týmy s lidmi, kteří tento typ nadání mají, aby z jejich výzkumů vznikalo něco, co je dětem srozumitelné a z čeho můžou těžit, radovat se anebo $\mathrm{k}$ tomu třeba zaujmout kritický postoj. Symbióza s autory dětské literatury může být pro studia dětství vůbec zajímavá. Pokud chtějí autorky a autoři dětské literatury, aby děti jejich knihy četly, musí jim skutečně dobře rozumět, musí výborně znát dětskou perspektivu. Proto by mezi povinnou četbou výzkumníků a výzkumnic v této oblasti neměly chybět oblíbené knihy dětí věkové kategorie či subkultury, kterou hodlají zkoumat.

Snaha o vymanění dětí z pozice pasivního výzkumného objektu se odráží i v př́stupu k získávání informovaného souhlasu dětí s výzkumem. Švaříček připomíná, že v českém školním prostředí se při výzkumech výzkumníci často spokojí s tzv. předpokládaným souhlasem, kdy se vstupem výzkumníka do terénu souhlasí osoba povolující realizaci výzkumu ve škole, obvykle ředitel/ka školy, a jeho/její souhlas v sobě zahrnuje i svolení za osoby jí podřízené, tedy další vyučující a žactvo (Švaříček 2007: 46). Je obvyklé, že za žáky rozhodují vyučující a rodiče. Tato praxe odráží přesvědčení, že žáci základní školy nejsou dostatečně vyspělí $\mathrm{k}$ tomu, aby udělali rozhodnutí, a učitelé mají právo za ně rozhodovat. Švaříček tak naznačuje, že informovaný souhlas bychom měli získat i od dětí, nejen od jejich zákonných zástupců, což je zcela v souladu s požadavky studií dětství.

Nicméně kdo dělal výzkum $\mathrm{v}$ české škole, ví, že to $\mathrm{v}$ našem kontextu není tak snadné. Jdete-li do standardní české školy, kde není zvykem, aby se děti podílely na spolurozhodování, narazíte nejspíš na několik problémů. Jednak na neporozumění u vyučujících, proč si chcete svou vlastní práci takto komplikovat a dohadovat se o něčem s dětmi. Dále na obtíže $\mathrm{s}$ tím, jak dětem vysvětlit, o co vám ve vašem výzkumu jde, aby souhlas byl skutečně informovaný, udělený z vlastní vůle a s pochopením a porozuměním danému tématu. Jedna zahraniční kolegyně, též z postkomunistické země, která chtěla získat informovaný souhlas dětí, nalezla velmi vstřícnou paní učitelku, která měla pro její požadavek pochopení. Učitelka nejdříve dětem sama přetlumočila, co je dle ní cílem výzkumu, a posléze uložila dětem stejně, jako se to ukládá při psaní písemky, aby se samy podepsaly vedle podpisu rodičů na lísteček, který jim v minulém týdnu s výzkumnicí rozdaly. Informovaný souhlas nebyl ani informovaný, ani souhlas.

Sama jsem zažila něco podobného při etnografickém výzkumu o reprodukci genderu ve školní třídě. Nejprve jsem požádala učitelku, zda bych mohla dětem vysvětlit, o čem výzkum je, a diskutovat s nimi o tom, zda souhlasí, abych jej u nich ve tř́dě realizovala. Učitelka souhlasila. Když jsme však poprvé vstoupily do 6.A, kde měla třídnictví, nejdříve mne představila jako socioložku, ,...což je něco jako psycholožka, však si děcka jistě 
vzpomínáte na naši školní psycholožku, že?“, a uvedla, že mým cílem je zkoumat jejich třídu proto, aby se $\mathrm{v}$ ní klukům a holkám žilo lépe, aby se kluci chovali jako gentlemani a dívky jako dámy. Po tomto úvodu se mne povzbudivě otázala, zda chci ještě něco dodat. Měla jsem pocit, že nic dodat nelze, a poslušně jsem se posadila na určené místo $\mathrm{v}$ zadní lavici a na požadavek informovaného souhlasu získaného i od dětí jsem rezignovala.

Asi jsem se vzdala př́liš snadno. Nicméně později jsem přemýšlela o tom, jak by reagovaly děti, pokud by poprvé ve svém žákovském životě dostaly možnost s něčím nesouhlasit. Ba co víc, nesouhlasit s něčím, co se na ně opět chystají uvalit dospělí. Dopadla bych stejně jako moje polská kolegyně, která studovala na učitelku angličtiny, při své první hodině praxe? Nelíbily se jí autoritativní př́stup a tuhá disciplinace dětí v polských školách a řekla si, že ona to bude dělat jinak. A tak, když se první dítě způsobně přihlásilo a dotázalo se, zda může odejít na záchod, řekla: „To je samozřejmé. V mých hodinách se na takové věci nemusíte ptát, klidně běžte, když budete potřebovat.“. Poté se všechny děti zvedly a ze třídy odešly.

Výzkumník požadující informovaný souhlas od dětí v našem kulturním kontextu jaksi nezapadá do systému. Nechci tím však říci, že na něj má zcela rezignovat. Bude ovšem muset být opět při naplňování etických požadavků výzkumu kreativní. Informovaný souhlas obnáší dva kroky - nejdříve informovat, poté zjistit, zda děti mají o participaci ve výzkumu zájem. Oba kroky mají svá úskalí a oba vyžadují čas, nechceme-li je odbýt pouze formálně. Možná nepůjde dětem hned na začátku dobře vysvětlit, co nás ve výzkumu vlastně zajímá. Možná nevystačíme se standardními postupy, jako je diskuse v hodině. Můžeme např́klad vytvořit webovou či facebookovou stránku, kde srozumitelně popíšeme, o čem je náš výzkum, a umožníme diskusi o něm tam. ${ }^{5}$ Ostatně podepsaný lísteček se souhlasem je rutinou, která etický rozměr našeho výzkumu nijak zvlášt' neposílí. Etika ve výzkumu neznamená „pojistit se“ proti obvinění z neetičnosti podepsanými papírky, ale především neustále reflexivně přemýšlet o tom, co děláme a s jakými důsledky. Souhlasem dětí se detailně zabývají v článku „Researching with Young Children: Seeking Assent“ Sue Dockett a Bob Perry (2011). Zdůrazňují, že získávání souhlasu je proces, nikoli jednorázový akt. Ukazují, že i jednorázově projevený souhlas dítěte může být spíše snahou dítěte nezklamat očekávání dospělých, a za nejvhodnější přístup považují vytváření specifického prostředí, ve kterém děti mají možnost budovat svou agency a aktivně se zapojovat, stejně jako vyjádřit přání spolupráci ukončit.

\section{Nejen mluvit, ale i rozumět}

Dětské výpovědi v úvodu tohoto článku se vztahují $\mathrm{k}$ představám dětí o čase. Co znamená „dlouho“ nebo „starý“ pro pětileté či desetileté dítě? Jakou má představu o dějinném plynutí času? Je mezi dobou mamutů a narozením prababičky takový rozdíl? Obojí je to prostě nepředstavitelně dávno. Tento př́iklad zde však neuvádím proto, abychom se zamýšleli nad rozdílným vnímáním času u dospělých a dětí. Chci se zmínit o obecnějším problému, kterému je třeba při výzkumu dětí čelit, a to je práce s kategoriemi dané disciplíny, která děti

5 Ovšem budeme muset ověřit, zda mají děti přístup k internetu. 
zkoumá. To, pro co my dospělí v našich kulturních končinách máme víceméně shodné předporozumění, jako je například plynutí času, může v dětském světě fungovat docela jinak.

Pro pozitivistickou vědu to nebyl žádný problém. Vývoj dítěte, jeho projevy či problémy se kategorizovaly, katalogizovaly a bylo jedno, nakolik taková kategorizace odpovídá dětské perspektivě. Dítě bylo pasivním objektem vědy. Studia dětství ovšem přistupují k dětem jinak, chtějí mluvit jejich jazykem. Je zřejmé, že se musí naučit komunikovat s dětmi jazykem a prostředky přiměřenými jejich věku či subkultuře, ale je třeba dát si pozor i ve stadiu interpretace.

Pro rozvinutí svého argumentu využiji tezí z článku Karolíny Vránkové, která v týdeníku Respekt prezentovala výzkum Lenky Slepičkové, Michaely Bartošové, Kateřiny Dvorákové a Beatrice Chromkové Maney ${ }^{6}$ (Vránková 2012). Vránková v článku uvádí, že výzkumnice př̌i zkoumání dětských představ o rodině došly $\mathrm{k}$ závěru, že děti jsou konzervativní a že „zatímco ve světě dospělých zuří postmoderna s alternativními rodinnými pořádky, děti o žádné nové modely nestoji“ (Vránková 2012: 72). Otázku, zda ve světě dospělých skutečně zuří postmoderna, ponechejme nyní stranou, toto tvrzení zpochybňuje naprríklad Lišková (2011). Brněnské výzkumnice se ptaly dětí na to, jak si představují vlastní budoucnost a budoucí rodinu, zjišt'ovaly, co si žákyně a žáci třetí a sedmé třídy myslí o jiných modelech rodiny, než je táta, máma a děti, a jaká mají očekávání od vlastních rodičů. Zjistily, že u dětí převládají tradiční představy o rodině - maminka, tatínek a děti, nejčastěji dvě. Modely, ve kterých figurovali na obrázku např́klad dva muži a batole, děti odmítaly. Identifikovaly, kdo chybí do „normálního“ složení, a hledaly pro nestandardní vyobrazení vysvětlení, například úmrtí ženy.

Můžeme ale tato zjištění interpretovat tak, že jsou děti konzervativní? Dovoluji si tvrdit, že nikoli. Domnívám se, že spíše než o konzervativnosti dětského smýšlení svědčí tyto výsledky o prokazování kompetencí, které si děti osvojily. Ačkoli se autorka článku domnívá, že ve světě dospělých zuř́ postmoderna, ve světě, který je prezentován dětem, postmodernu aby člověk pohledal. Prohlédneme-li slabikáře i jiné učebnice, pročteme-li dětská ř́kadla a pohádky, alternativních modelů mnoho nenajdeme. Podstatou socializace dětí je, aby se naučily společenská pravidla, aby si osvojily normy a hodnoty. Děti poměrně záhy pochopí, že existují různé sociální hierarchie, a tou první, kterou mají možnost zažít, je hierarchie věková. Dítě, které je starší a předpokládá se, že i vyspělejší, je oceňováno. S věkem a kompetencemi rostou práva a autonomie dětí. Dítě ví, že je chváleno (ty jsi velká holka/velký kluk) za to, když už dokáže správně určit, jakou barvu mají různé předměty, jaké oblečení patří na kterou část těla apod. Od předškolního věku jsou děti institucemi testovány, zda dostatečně rozvinuly sociální kompetence. Pokud se jich zeptáme na to, jak si představují vlastní rodinu, není divu, že nám předvedou přehlídku kulturních ikon - rodina je táta, máma a děti, i kdyby to zrovna u nich doma nebo u sousedů vypadalo nějak jinak. Děti rozumí nejen normám, ale i sankcím za jejich porušování. Být kupríkladu „,z rozvedené rodiny“ anebo dítětem, „,na které

6 Je to poněkud nefér, protože nejde o odbornou publikaci a já hodlám své kolegyně trochu kritizovat na základě mediální výpovědi o jejich práci. Odborný zdroj s výsledky výzkumu však nebyl k dispozici a doufám, že mi prominou a př́padně budou kontrovat $\mathrm{v}$ odpovědi na mou kritiku $\mathrm{v}$ další diskusi, již na stránkách odborného tisku. 
je matka sama“, nemá dobrý zvuk ani v kolektivních institucích, jako školka či škola, ani v širších příbuzenských kruzích. A rodiny dvou žen nebo mužů či nějaká kolektivní uskupení, to jsou představy doslova z říše science fiction. Bez významu není ani to, kde se dětí ptáme. Pokud výzkum probíhá ve škole, dostaneme ,školní“ odpověd', tj. děti budou odpovídat podobně jako při písemce či při testu v pedagogicko psychologické poradně.

Pokud bych jako výzkumnice chtěla zjistit něco víc o tom, jakou roli hraje rodina v představách dětí, zkusila bych se soustředit na dětskou hru. Se sestrou jsme si často hrály s Barbínou a dvěma Pamelami (něco jako malé Barbíny). Př́běh nejčastěji vypadal takto: Barbína přijíždí do nového města jako osamělá matka $s$ oběma Pamelami. Jsou chudé. Barbína si musí sehnat práci, aby vydělala dost pro všechny tři. Nejdůležitější institucí $\mathrm{v}$ daném městě je obchod. $\mathrm{V}$ něm se nacházejí nejskvělejší šaty a šperky, po kterých především Pamely touží. Barbíně by samozřejmě taky slušely, ale ona ví, že životní hodnoty spočívají v něčem jiném, než jen v krásných šatech (po tom všem co prožila tam, odkud do města přišla). Pamely zpočátku nemají ani slušné oblečení, aby mohly chodit do školy. Barbína se uchytí a postupně vydělá, jak na slušné oblečení do školy, tak na luxusní šaty na plesy. Pak se ale stane něco hrozného a Barbína opět o všechno prrijde a musí luxusní zboží prodat, aby vůbec zaplatila nájem a jídlo. Ve městě žijí ještě poníci - matka Anna s malým poníkem Bambinem. Anna Barbíně pomáhá, aby ona sama nebo Pamely nemusely sejít na šikmou plochu.

Kdybych jako výzkumnice sledovala tuto hru, zajímalo by mě, kde jsou mužské postavy. Co to vypovídá o dětských představách o rodině a genderu? Námitku, že šlo možná o specifický způsob hry, který se odehrával jen v našem dětském pokoji, by mohly vyvrátit statistiky prodejnosti Barbínina hračkového partnera Kena. O hrách s panenkou Barbie, které zdaleka neodpovídají hře na tradiční rodinu, píše také např́ílad Naomi Wolf v knize Promiscuities (1997: 14-17). ${ }^{7}$

\section{Techniky sběru dat při výzkumu s dětmi}

Nechci však tvrdit, že př́mé pozorování dětí je jedinou možnou technikou vhodnou pro výzkum dětí. Projektivní techniky, kdy děti kreslí, píši krátké texty, diskutují o obrázcích či filmu nebo třeba hrají dramatické scénky dle zadání výzkumnic/výzkumníků jsou velmi vhodné. Tyto praktiky děti znají, odpovídají tomu, na co jsou zvyklé z vyučování nebo $\mathrm{z}$ organizovaných volnočasových aktivit. Je pouze důležité si uvědomit, že tím, kdo nastavuje rámec dětské výpovědi $\mathrm{v}$ těchto technikách, jsou stále dospělí - předkládají dětem

Anonymní recenzentka této statě navrhla další vysvětlení nízké obliby Kena a větší obliby panenek ztělesňujících holčičí a ženské postavy: „Příčiny bych hledala spíše v atraktivitě doplňkủ a převleků, které se k nim nabízejí - oč je roztomilejší růžový střevíček než plastová bílá teniska s vylisovanými tkaničkami! Kenovi se navíc nedají česat vlasy a upravovat účesy a těžko mu budeme oblékat plesové či svatební šaty a střídat kabelky. S panenkami je zkrátka větší zábava (zcela pomíjím otázku dívčí identifikace s panenkou) a když může mít dívka například jen jednu nebo dvě, sáhne spíše po nich.“ Osobně bych neřekla, že jde o alternativní vysvětlení vylučující mnou naznačený směr interpretace, ale o doplnění téhož. 
zadání, které je strukturováno dospělým uvažováním výzkumníka, a je třeba uvažovat o tom, do jaké míry bude strukturovat i dětskou odpověd'. Bez významu není ani to, v jakém prostředí dětem tyto techniky předložíme, zda to bude během školního vyučování, $v$ nějakém zájmovém kroužku či družině, anebo se pokusíme pracovat s dětmi mimo instituce, např́íklad na dětském hřišti. Nejčastěji bývají výzkumy realizovány při školním vyučování, nebot' je to organizačně nejsnazší. Děti se vyučování povinně účastní, jsou zvyklé na to, že plní úkoly, které jim zadají dospělí v roli vyučujících (ze své výzkumné praxe vím, že i jako výzkumnice, která nabídne dětem tykání, jsem stále z pohledu dětí v roli učitelky), vědí, že na zadané otázky se má odpovídat „správně“, tzn. sdělovat nikoli nutně to, co si myslím, ale to, co se očekává. Popř́padě lze výzkumu využít $\mathrm{k}$ subverzi moci dospělých - a naschvál odpovědět „špatně“, udělat pravý opak toho, co se dítě domnívá, že se očekává, napsat něco, co si myslí, že dospělého naštve.

Tuto zkušenost jsem udělala během svého disertačního výzkumu na téma reprodukce genderu ve školní tř́idě (Jarkovská 2010). Chtěla jsem zjistit, jakou roli hraje gender v představách dětí a během svého ročního pobytu $\mathrm{v}$ základní škole jsem dětem šesté třídy zadala úkol napsat text na téma: „Co by v mém životě bylo jinak, kdybych byla kluk? / Co by v mém životě bylo jinak, kdybych byl holka?" Několik chlapců napsalo velmi krátkou odpověd’, která byla variací na větu „musel bych si tam strkat vibrátor“. Bylo zřejmé, že kluci chtějí provokovat. Nejdříve jsem byla touto odpovědí zklamaná a domnívala jsem se, že mi na mou otázku neodpověděli, jen si ze mě dělají legraci a chtějí provokovat. Díky dlouhodobému pobytu ve škole jsem si ale tuto jejich odpověd' mohla zasadit do kontextu jejich života ve třídě a při hlubším promýšlení mi došlo, že mi vlastně odpověděli zcela přesně na to, co pro ně znamená gender. Nepopsali to verbálně, ale performativně - být chlapcem znamená jednak performovat maskulinní heterosexualitu, vyvarovat se každé i fantazijní situace, ve které by mohli být kontaminováni ženským genderem, a také budovat postavení v rámci (chlapeckého) kolektivu tím, že budou budovat image „desperáta“, k čemuž se dobře hodí provokace dospělé osoby.

Vedle projektivních technik, které představují aktivitu na pomezí zábavy a školní úlohy, se nabízí také klasické výzkumné techniky, jako je dotazník či rozhovor. U obou těchto technik je nanejvýš vhodné strávit také určitou dobu v terénu a ušít je dětem, se kterými realizujeme výzkum, př́mo na míru. Speciálně v př́ípadě dotazníku je tu, jak se domnívám, obrovské riziko, že nebude validní, pokud ho připravíme bez znalosti respondentů, a nebudeme si moci být vůbec jisti tím, jak děti otázce porozuměly a co jejich odpověd’ znamená. Pro dotazník i rozhovor je třeba se naučit jazyk dětí, které chceme do výzkumu zapojit. ${ }^{8}$ A v závislosti na schopnostech dětí promyslet také odpovídající délku a vhodnost použité techniky.

8 O významu překladu do různých typů jazyka pro sociologický výzkum viz např́klad Petrusek (1993). 


\section{Ełnografie jako řešení}

Žádná technika ve výzkumu dětí není a priori nevhodná. Je však vždy žádoucí promyslet ji $\mathrm{v}$ kontextu zkoumaného pole, a $\mathrm{z}$ toho důvodu se pro výzkum dětí z perspektivy studií dětství hodí etnografický design výzkumu, ve kterém můžeme techniky kreativně kombinovat, ověřovat a přizpůsobovat. Cílem tohoto článku není komplexní pojednání o tom, jak dělat etnografii ve výzkumu dětí, ten podá např́iklad článek Roberta A. Levina shrnující etnografický výzkum dětství ve 20. století (Levin 2007) či kapitola „Ethnography in the Study of Children and Childhood“ od Allison James v Handbook of Ethnography (James 2001), v českém kontextu stojí za pozornost kupř́kladu článek Kateřiny Nedbálkové „Jedna ruka kreslí druhou aneb Jak se dělá etnografický výzkum“ (2007) v učebnici Kvalitativni výzkum v pedagogických vědách editované Romanem Švařičkem a Klárou Šed’ovou. Mým záměrem bylo zdůraznit přednosti etnografického výzkumného designu, a to především z důvodu kontextualizace získávaných dat.

I etnografie má však svá úskalí, se kterými je třeba se vyrovnávat. Kromě časové náročnosti a problémů při vyjednávání vstupu do terénu, kdy pro mnohé osoby, s nimiž chceme dělat výzkum, je daleko srozumitelnější dotazník než požadavek na dlouhodobé spolupobývání, jsou to také problémy epistemologické povahy - jakým způsobem rozumíme datům, která skrze etnografický výzkum získáváme? Interpretativní etnografie je osobní a zároveň kriticky reflexivní proces. To, co $\mathrm{v}$ terénu prožíváme, se stává součástí našeho vlastního života. Jde o situovanou metodu, která odráží specifické a jedinečné vidění autora, a jejím výsledným produktem je porozumění zkoumanému z určité perspektivy, zachycení faktu ustavovaného v proměnlivé rétorice (Goodall in Alexander 2003: 436). Ačkoli budeme usilovat o perspektivu dětí, které se budeme moci díky dlouhodobému pobytu v terénu přiblížit, vždy to nakonec bude naše vlastní perspektiva. Proto musí výzkumnice/výzkumník reflektovat svoji subjektivní pozici. Denzin tento proces nazývá standpoint reflexivitou (1997). Výzkum s dětmi a specificky výzkum realizovaný ve škole představuje výzkum v prostředí, které všichni důvěrně známe, nebot' jsme v něm strávili mnoho let svého života, a jak uvádí Thorne, všechny socioložky a všichni sociologové byli jednou dětmi (1987). To však v sobě skrývá nebezpečí, že zkoumané prostředí bude pro výzkumnici/výzkumníka př́lišs samozřejmým, popř́ipadě, že kolonizuje zkušenost dětí svou vlastní zkušeností.

K této otázce se vyjadřuje také Claudia Castañeda, která upozorňuje na fakt, že feministické teoretičky sice přispěly $\mathrm{k}$ rekonceptualizaci dětství a subjektivity dětství, ale i přes značný posun se mnohdy nevystř́haly toho, aby samy dětství neokupovaly z pozice dospělých (Castañeda 2001). Z tohoto hlediska přezkoumává analýzu uskutečněnou Valerií Walkerdine. Walkerdine v knize Daddy's Girl (1997) analyzuje mediální reprezentace malých holčiček, a to jak $\mathrm{z}$ hlediska toho, jakým tyto reprezentace promlouvají $\mathrm{k}$ dospělým fantazím o dětství, tak z perspektivy dívek, tj. toho, jakou hrají roli při utváření dívčí subjektivity. Castañeda tvrdí, že Walkerdine se nepodařilo vyhnout se okupaci dětství svým dospělým já. Walkerdine využívá jako sebereflexivní metodologicko-teoretickou strategii vzpomínky na své vlastní dětství, které prožila jako dívka $\mathrm{z}$ dělnické rodiny. Walkerdine se identifikuje s dělnickými dívkami, tím však podle Castañedy vyvlastňuje subjektivitu současných dělnických dívek a na její místo klade své vzpomínky, které jsou nikoli zkušeností dívek, ale vzpomínkami dospělé, nikoli už dělnické ženy. Její vzpomínky jsou reinterpretacemi někdejších zážitků, 
přefiltrovanými teoretickým zázemím výzkumnice, především psychoanalýzou. Castañeda se domnívá, že Walkerdine nereflektovala dostatečně svou pozici dnes už dospělé ženy, a stejně tak nereflektovala svi̊j vztah k dívkám skrz tuto pozici. Walkerdine podle ní opomíjí své privilegované postavení dospělé akademičky, která již není výzkumnicí s dělnickou identitou, opomíjí nerovný vztah mezi ní a dělnickými dívkami, se kterými pracovala (Castañeda 2001: 38). Z toho vyplývá, že výzkumník musí s vlastními zážitky a vzpomínkami aktivně pracovat a reflektovat, že jde o vzpomínky přefiltrované dalšími zkušenostmi i teoretickým sociálně-vědným tréninkem. Jako př́klad může sloužit práce Barrie Thorne, která ve své analýze nazvané Gender Play (2004) používá vlastní vzpomínky z dětství jako kontrapunkt $\mathrm{k}$ linii hlavního př́iběhu, který vypráví už jako výzkumnice. Když etnograf/ka vypráví př́iběh těch, se kterými dělal/a výzkum, nemůže nikdy mluvit ,jejich hlasem“. Mluví svým vlastním hlasem, jakkoli dobře se jí/mu podařilo se zkoumaným přibližit a porozumět jim.

\section{Závěrem}

V tomto metodologicky orientovaném textu jsem se pokusila poukázat na úskalí, se kterými se setkáváme při výzkumu, chceme-li ho stavět na požadavcích studií dětství. Žádný výzkum nemůže být z metodologické ani etické stránky dokonalý. Dobrý metodologický postup a etický př́istup se vyznačují tím, že nezastíráme, že volíme z několika cest, přičemž ani jedna není ideální. Pokud má výzkum ambici zdůraznit roli dítěte jako aktéra a chce uplatňovat jeho perspektivu, je nezbytné věnovat výzkumu a dětem hodně času. Dlouhodobé pobývání v terénu, které bude zahrnovat neformální rozhovory s dětmi a budování vztahu s nimi, nám umožní jak kreativní rozvíjení metodologie, tak promýšlení etických rozměrů našeho bádání ve vztahu ke konkrétním dětem. Interakce s dětmi nás může inspirovat $\mathrm{i} k$ inovativnímu zpracování výsledků tak, aby nepředstavovaly pouze „př́nos vědeckému poznání“, ale aby z nich měly užitek i př́mo námi zkoumané děti či jejich vrstevníci, jako tomu bylo v př́ipadě učebnice o chudobě. Etnografický postup a př́má pozorování umožňují trávit s dětmi čas způsobem, který nenadefinoval sám design výzkumu. Jedině pak je možné ověrit, zda témata, o kterých jsme přiměli děti uvažovat, jsou pro děti relevantní i bez našeho výzkumu. Dostatek času je tedy nezbytným předpokladem pro realizaci výzkumu na principech a požadavcích studií dětství. Těm sice nelze dostát beze zbytku, nicméně pokud si na to uděláme čas a ponoř́me-li se do světa dětí, můžou se i na první pohled svazující pravidla a požadavky proměnit v tvůrčí potenciál, který stimuluje sociologickou imaginaci.

\section{Literatura}

ALANEN, Leena. Editorial: Critical Childhood Studies? In Childhood, 2011, č. 2, vol. 18, s. 147-150. ISSN 0907-5682.

ALEXANDER, Bryant Keith. (Re) Visioning the Ethnographic Site: Interpretive Ethnography as a Method of Pedagogical Reflexivity and Scholarly Production. Qualitative Inquiry, 2003, č. 9, vol. 3. ISSN 1046-2937.

ÁRIES, Philippe. Centuries of Childhood: A Social History of Family Life. New York : Vintage Books, 1962. ISBN 0394702867. 
BADINTER, Élisabeth. Materská láska: od 17. storočia po súčasnost'. Bratislava : Aspekt, 1998. ISBN 80-85549-04-2

CASTAÑEDA, Claudia. The Child as a Feminist Figuration: Toward a Politics of Privilege. Feminist Theory, 2001, č. 2, vol. 1, s. 29-53. ISSN 1464-7001.

CORSARO, William A. The Sociology of Childhood. Thousand Oaks : Pine Forge Press, 1997. ISBN 0803990111.

DENZIN, Norman K. Interpretive Ethnography: Ethnographic Practices in the 21st Century. Thousand Oaks, CA : SAGE, 1997. ISBN 0-8039-7299-7.

DOCKETT, Sue, PERRY, Bob. Researching with Young Children: Seeking Assent. In : Child Indicators Research, 2011, č. 2, vol. 4, s. 231-247. ISSN: 1874-897X.

GILl-PIĄTEK, Hanna, KRZYWONOS, Henrika. Bieda. Przewodnik dla dzieci. Warszawa : Wydawnictwo Krytyki Politycznej, 2010. ISBN 978-83-62467-02-0.

HARDING, Sandra. The Science Question in Feminism. Ithaca : Cornell University Press, 1986. ISBN 0801493633.

JAMES, Allison. 2001. Ethnography in the Study of Children and Childhood. In ATKINSON, P., COFFEY, A., DELAMONT, S., LOFLAND, J., LOFLAND, L. (eds.). Handbook of Ethnography. London : SAGE, 2001. s. 246-257. ISBN 076195824X.

LEVINE, Robert A. Ethnographic Studies of Childhood: A Historical Overview. American Antropologist, 2007, č. 2, vol. 109, s. 247-260. ISSN 0002-7294.

LIŠKOVÁ, Kateřina. Released from Gender? Reflexivity, Performativity, and Therapeutic Discourses In : BENSON, M., MUNRO, R. (eds.). Sociological Routes and Political Roots. Oxford : Blackwell, 2011. s. 189-204. ISBN 978-1-4443-3813-3.

MILLMAN, Marcia, KANTER, Rosabeth Moss (eds.). Another Voice. Feminist Perspective on Social Life and Social Science. New York : Anchor Books, 1975. ISBN 0385040326.

NEDBÁLKOVÁ, Kateřina. Etnografie (Jedna ruka kreslí druhou aneb Jak se dělá etnografický výzkum). In ŠVǍ̌́ǏČEK, R., ŠEĎOVÁ, K. (eds.). Kvalitativni výzkum v pedagogických vědách. Praha: Portál, 2007. s. 112-125. ISBN 978-80-7367-313-0.

PETRUSEK, Miloslav. Teorie a metoda v moderni sociologii. Praha : Karolinum, 1993. ISBN 80-7066-799-0.

PROUT, Alan, JAMES, Allison (eds.). Constructing and Reconstructing Childhood. London : Flandr, 1997. ISBN 0750707038.

SHORTER, Edward. The Making of the Modern Family. London : Collins, 1976. ISBN 0002115425.

ŠVAŘÍČEK, Roman. Kritéria kvality kvalitativního výzkumu. In ŠVAŘÍČEK, R., ŠEĎOVÁ, K. (eds.). Kvalitativní výzkum v pedagogických vědách. Praha : Portál, 2007. s. 28-50. ISBN 978-80-7367-313-0.

THORNE, Barrie. Re-visioning Women and Social Change: Where Are the Children. Gender \& Society, 1987, č. 1, vol. 1, s. 85-109. ISSN 0891-2432.

THORNE, Barrie. Gender Play: Girls and Boys in School. Buckingham : Open University Press, 2004. ISBN 0-8135-1923-3.

VRÁNKOVÁ, Karolína. Máma, táta, hlavně pes. Respekt, 2012, č. 1, s. 71-73. ISSN 0862-6545.

WALKERDINE, Valerie. Daddy's Girl. Young Girls and Popular Culture. Basingstoke : Palgrave Macmillan, 1997. ISBN 0333647793.

WOLF, Naomi. Promiscuities: the Secret Struggle for Womanhood. 1st ed. New York : Fawcett Columbine, 1998. ISBN 0449907643.

WOODHEAD, Martin. Childhood studies. Past, Present and Future. In KEHILY, Mary Jane (ed.). An Introduction to Childhood Studies. Maidenhead : Open University Press, 2009. s. 17-34. ISBN 0-335-22870-4.

WYNESS, Michael. Childhood and Society. London : Palgrave Macmillan, 2006. ISBN 0-333-94648-0. 
SOCIÁLNÍ STUDIA 2/2012

\section{Autorka}

Lucie Jarkovská vystudovala sociologii na Masarykově univerzitě, kde v současné době působí jako odborná asistentka na oboru genderových studií na katedře sociologie Fakulty sociálních studií. Věnuje se výzkumu v oblasti genderové socializace a genderových aspektů školství, zabývá se sexuální výchovou. Působí také jako lektorka v oblasti genderově citlivé pedagogiky.

Kontakt: FSS MU, Joštova 10, 60200 Brno, e-mail: jarkovsk@fss.muni.cz 